\title{
elyra
}

\section{O texto como espetáculo}

\section{Lígia Souza de Oliveira}

\section{Universidade São Paulo}

Resumo: Como primeira parte da pesquisa de doutorado sobre a obra do dramaturgo franco suíço Valère Novarina - desenvolvida no Programa de Pós-Graduação em Artes Cênicas da Universidade de São Paulo - se fez necessário uma reflexão acerca da condição do texto teatral na contemporaneidade, haja vista que a grande parte das produções teatrais da atualidade se constroem a partir da rejeição dos preceitos do drama burguês e com isso, da ideia de textocentrismo. Neste artigo discutiremos alguns pontos das teorias de Peter Szondi, Hans-Thies Lehmann, Mary Lewis Shaw, Marco Di Marinis, Stephan Baumgartel, Luiz Fernando Ramos e outros, fazendo convergir suas teorias para construção de uma reflexão acerca da problemática do texto na contemporaneidade. A partir desse percurso pretendemos discutir como as produções textuais para o teatro se aliam e se distanciam da teoria e da prática teatral, debatendo mais a fundo a falsa oposição entre texto e cena na atualidade.

Palavras-chave: Dramaturgia, textocentrismo, espetáculo

Abstract: As a first part of the development of the doctoral research about the work of Swiss-Swiss playwright Valère Novarina, developed in the Post-Graduate Program in Performing Arts of the University of São Paulo, it was necessary to reflect about the condition of the theatrical text in contemporary times, as proved by the great part of the theatrical productions of the present time are constructed from the rejection of the precepts of the bourgeois drama and with this, of the idea of textcentrism. In this article we will discuss some points of the theories of Peter Szondi, Hans-Thies Lehmann, Mary Lewis Shaw, Marco Di Marinis, Stephan Baumgartel, Luiz Fernando Ramos and others, converging their theories to construct a reflection about the problematic of contemporary text. From this course we intend to discuss how the textual productions for the theater are allied and distanced from theatrical theory and practice, further debating the false opposition between text and scene in the present time.

Keywords: Dramaturgy, textcentrism, show 


\subsection{Gênero Lírico}

A revolução iniciada a partir da recusa dos princípios do teatro burguês, desembocou na necessidade de repensar a hegemonia do texto e transformar os paradigmas do teatro no fim do século XIX. Essa restauração de valores, até então base das artes cênicas que ainda hoje desdobra seus efeitos, abriu possibilidades diversas na construção de não só um, mas de vários preceitos da linguagem cênica, transformando completamente a função e a criação de todos os elementos que a compõe.

A partir da oposição à soberania do texto teatral, as produções acabaram ou por horizontalizar a importância dos elementos ou, em outros casos, por supervalorizar as questões da materialidade do teatro, chegando inclusive ao outro oposto, o cenocentrismo.

Certamente a dramaturgia é a linguagem que mais luta para se opor ao formato enrijecido do drama, sendo muitas vezes taxada como a responsável pela existência de produções tradicionais na atualidade. Diante disso, os ícones da derrubada do drama ao longo do século XX são, principalmente, artistas teatrais que se dedicam a pensar e elaborar uma cena que denote a autonomia do teatro, partindo, geralmente, da construção cênica atuação, cenário, iluminação e etc.

Porém, foi justamente a dramaturgia que iniciou um movimento que desembocou na quebra dessa soberania, como nos indica Peter Szondi, em seu Teoria do Drama Moderno. O teórico cita os textos de dramaturgos como Ibsen, Strindberg, Tchekhov, Hauptmann e Maeterlink que sinalizaram em suas obras os primeiros aspectos de transição do teatro, e ilustram o que Szondi chamou de crise do drama. O pensamento construído neste livro parte do entendimento filosófico da estrutura do drama hegeliano, para então evidenciar as contradições que surgiram em determinadas obras, revelando os diferentes direcionamentos estruturais e temáticos.

É justamente a partir do pensamento acerca dos gêneros literários discutidos por Hegel, que Szondi indica a entrada do épico no seio das novas produções. Discutindo a relação entre forma e conteúdo, o teatrólogo segue nos apontando em cada texto teatral a evidência de que é a epicização do drama a maior responsável pela revolução da linguagem no século XX. Ele indica a desconexão entre forma e conteúdo como a principal mudança na quebra da estrutura dramática que encaminha para o avanço do épico: "a peça social 
burguesa, que outrora adotara o princípio formal do drama clássico, converte-se em épica a partir da contradição forma e conteúdo desenvolvido no curso do século XIX" (Szondi 2001: 68).

Em contraposição a esta visão, a pesquisadora Cleise Furtado Mendes evidencia diversos pontos que problematizam a visão de Szondi. Ela acredita que "apenas a vertente épica foi devidamente identificada e valorizada pelos autores que se debruçaram sobre a multifacetada produção dramatúrgica que emerge nas primeiras décadas do século XX" (Mendes 2015: 07).

Diante disso, Mendes indica a necessidade de perceber exatamente nas mesmas obras citadas por Szondi uma origem lírica que desemboca na restauração da dramaturgia. Ela não pretende, dessa maneira, substituir o drama moderno épico. Pelo contrário, a intenção da pesquisadora é dar luz às estruturas típicas do lírico que estão na base da construção de algumas obras teatrais. Contudo, Mendes não ignora as contribuições diversas que desembocaram na reinvenção da linguagem.

Jean-Pierre Sarrazac, teórico francês, defende em seu Léxico do Drama Moderno e Contemporâneo, uma revisão do estudo unilateral de Szondi:

Trata-se - repetimos - de abandonar a ideia segundo a qual o horizonte - o fim - do teatro dramático poderia ter sido o teatro épico (como o do capitalismo deveria ser o comunismo). Para isso, não há necessidade alguma de se rejeitar o marxismo e, tampouco, a abordagem socioestética do teatro moderno e contemporâneo. Basta, ao contrário, interrogar-se sobre certas rejeições ideológicas de pensadores marxistas do teatro [...] e proceder a uma reavaliação dos objetos rejeitados: principalmente o "dramático" (não mediatizado pelo "épico") e seu corolário, a subjetividade, polemicamente rebatizada como "subjetivismo". (Sarrazac 2012: 30)

Nesta direção, Cleise Furtado Mendes concorda com a leitura de Sarrazac e a partir dele constrói um argumento oposto ao de Szondi. Porém, a pesquisadora nos esclarece que as indicações de Sarrazac ainda desembocam na criação de uma teoria épica no teatro: o seu Drama Rapsodo. Na concepção de Sarrazac, a noção de rapsódia aparece, portanto, ligada ao domínio épico, à narração homérica e à procedimentos de escrita tais como a montagem, a hibridização, a colagem e a coralidade (Idem: 152). 
Como veremos abaixo, acreditamos que os aspectos do lírico se tornaram mais frutíferos para a reconstrução do texto do que para os outros elementos do teatro. Se trata de perceber aqui, como fez Szondi em relação ao épico, as características do lírico que auxiliaram na desestabilização do formato do drama e na instauração de novas, porém não mais soberanas, possibilidades da dramaturgia. Mendes enumera as seguintes propriedades:

O predomínio da função poética sobre a representativa na linguagem; a união de som e sentido, com ênfase na música das palavras; fusão de sujeito e objeto da percepção; subjetivação de espaço e tempo; presença da repetição como recurso de fazer perdurar o fluxo lírico, com uso de estribilhos e variações temáticas; recusa da lógica sintática, com predileção por construções paratáticas (com partes coordenadas, livres de hierarquia), entre outros. (Mendes 2015: 09)

Com isso, podemos afirmar que a percepção de aspectos líricos no cerne da dramaturgia se dá principalmente na transformação de uma configuração pautada na intersubjetividade (baseada na relação entre os personagens através do diálogo) para estruturas diversas que demonstram a intrassubjetividade (questões que emergem do embate consigo mesmo) dos seus personagens. Isso não denota, absolutamente, um individualismo ou isolamento em relação às temáticas sociais. Mendes acredita que o lírico produz o movimento de "abrir-se da intimidade das personagens para o espetáculo do mundo" (Idem: 15).

Como dizemos anteriormente, essa entrada do lírico como ação estruturante para a reinvenção da dramaturgia ainda aparece na nossa bibliografia teórica de maneira tímida e desconfiada. Indicada como Drama lírico, Poema dramático, Teatro Íntimo, Teatro Estático, Teatro da Fantasia, e outros, ela ainda é tida como coadjuvante nas reflexões acerca da cena contemporânea. Isso se deve principalmente ao fato das contribuições do lírico serem muito mais da ordem do texto teatral do que do espetáculo em si. Conforme Sarrazac "embora explorem o poder da fala, nem por isso deixam de levar em conta a materialidade da cena" (Sarrazac 2012: 141).

Isso se dá justamente pelo fato de que o texto foi tido como fator central para a soberania do drama. Logo, qualquer movimento de transformação da linguagem cênica que seja iniciado a partir da palavra é tido como uma volta ao textocentrismo dramático ou à exaltação da literatura no palco em detrimento das questões da autonomia do teatro. 
O que pretendemos aqui, também, é demonstrar como o texto foi e ainda é fator decisivo para a reinvenção das artes cênicas desde o século XIX, e indicar que a entrada do gênero lírico no teatro trata, principalmente, de um recurso fundante na reestruturação do texto fora dos parâmetros do drama.

Para Sarrazac, o desenvolvimento do lírico no teatro se dá principalmente nas dramaturgias dos simbolistas: "radicalizado por Mallarmé, e reivindicado por alguns dramaturgos simbolistas (Maeterlink e Yeats) ou por Hofmannsthal, o poema dramático substituiu a observação realista por uma visão fantasista, irreal ou interiorizada do mundo, privilegiando a sugestão e a emergência de uma voz lírica" (Ibidem).

\subsection{Poética Simbolista}

O Simbolismo se inicia na França por volta de 1885 como uma forte resposta aos avanços industriais e aos movimentos filosóficos e artísticos que deles derivavam. As filosofias do determinismo, evolucionismo e positivismo eram o auge do pensamento do século XVIII, em que todos os fenômenos poderiam ser explicados a partir do racional. Dessa forma, inclusive a figura homem era considerada como uma peça pequena diante da imensidão do universo e todos os seus conflitos se tornaram passíveis de explicação objetiva.

Herdeiro do swedenborguismo, o Simbolismo surge revelando uma desconfiança diante do cenário racional e se coloca a favor da intuição e da subjetividade, evocando a necessidade de se perceber o homem a partir de questões da metafísica. Essa descrença nos avanços científicos acaba por instaurar um espírito decadente, um dos aspectos motores do Simbolismo segundo a pesquisadora Anna Balakian.

Deste espírito decadente surge concomitantemente o movimento Decadentista, que tinha foco na filosofia e nas inquietações humanas, sem ligação direta com a arte. Porém o Decadentismo possuía os mesmos preceitos: revolta e resistência ao materialismo e um forte pessimismo em relação ao homem e ao mundo, revelando também uma tendência à valorização das questões místicas e da ordem do intangível.

Já o Simbolismo, um movimento puramente artístico, tem sua produção mais forte na linguagem lírica. Não é consenso quais os poetas que representam o movimento, alguns 
são vistos como precursores, outros como descendentes da estética simbolista. Baudelaire, Verlaine, Rimbaud e Mallarmé são alguns deles.

Segundo a pesquisadora Balakian, as principais características do Simbolismo são a ambiguidade da comunicação indireta, a exaltação do espírito decadentista e a influência da música como retirada do logos. Para este momento, vamos nos ater somente a uma dessas especificidades.

A ambiguidade da palavra indireta, maior característica da poesia de Mallarmé, passa pelo entendimento da filosofia de Swedenborg, utilizada também por outras escolas literárias. O que nos interessa levantar aqui acerca do swedenborguismo é principalmente a ideia de correspondência na reflexão acerca da palavra. Em Balakian encontramos uma citação de Swedenborg:

\footnotetext{
Se o homem tivesse conhecimento das correspondências, compreenderia a palavra no seu sentido espiritual e obteria conhecimento das verdades escondidas, das quais nada vê no sentido das letras. Porque na palavra há um sentido literal e um sentido espiritual. O sentido literal insiste nas coisas como elas estão no mundo, mas o sentido espiritual, como elas são no céu; e desde que a união do céu com o mundo é realizada por correspondências, foi, portanto, fornecida uma palavra em que tudo tinha, no mínimo detalhe, sua correspondência. (apud Balakian 1985: 18)
}

Ao se aproximar do pensamento de Swedenborg, a poética simbolista apropria-se da palavra enquanto força evocativa, dando a elas o poder para além do uso cotidiano. $A$ palavra se torna então um disparador para experiências sensoriais e místicas, evocando as percepções do sonho, do sagrado e do intuitivo: "as palavras deveriam servir para revelar o poder mágico que contêm, em vez de serem usadas como explicações" (Idem: 109).

A exaltação pela ligação entre terra e céu desemboca num misticismo que se aplicou, acima de tudo, na utilização da palavra. Por se tratar principalmente de um movimento de poetas, a palavra se torna um símbolo e dá espaço para o lugar do leitor enquanto propositor de sentidos: "tentaram manifestar uma experiência supernatural na linguagem das coisas visíveis e assim quase toda palavra é um símbolo e é usada não em seu sentido comum, mas em associação com aquilo que ela evoca de uma realidade situada além dos sentidos" (Idem: 12). 
O símbolo tem como objetivo, portanto, ser o elo entre aspectos do mundo e do sagrado, relacionando as correspondências e transmitindo da linguagem oculta do universo. Nesse movimento, o poeta objetiva desenvolver através do símbolo aquilo que a ciência não consegue dar cabo. Eles atuam como que decodificadores dos sentimentos do homem e de suas inquietudes em relação à existência.

Já no teatro simbolista há, entorno de seus artistas, uma descrença e uma desvalorização das obras justificada pela sua forte aderência ao texto e pela valorização da palavra. Os principais representantes são Maurice Maeterlink, Alfred Jarry e W. B. Yeats.

O teatro simbolista não apresenta em suas obras a exaltação da ambiguidade da palavra de maneira substancial e enfática. Essa característica é uma especificidade maior do movimento poético. Mesmo assim, por conta do apego do teatro da época à materialidade das relações, os artistas simbolistas ainda são acusados de hermetismo.

Porém, vale destacar aqui o principal atributo de suas montagens: a substituição da ação pela situação. Levando à cena o espírito decadentista da época, as peças simbolistas davam espaço mais para reflexões existenciais, ou para a linguagem do sonho e da intuição do que para o embate entre os personagens. A ideia de situação se apresenta como um quadro estático no qual os personagens estão diante de um momento da sua vida e esperam que o destino se cumpra. Na maioria dos casos, segundo Peter Szondi, o destino é a morte.

Como apontamos anteriormente, um dos argumentos que alegam que o teatro simbolista não aconteceu em sua potência é o seu demasiado interesse na poeticidade, se aproximando mais da literatura do que do teatro. Por um lado, Jean Jacques Roubine afirma que

o textocentrismo é um dos pilares teóricos da encenação simbolista. É compreensível que assim seja, uma vez que se trata desde o início de um movimento de poetas (Paul Fort, Maeterlink) ou apoiado por poetas (Mallarmé) cuja ambição consistia em restabelecer os direitos do imaginário que a estética naturalista, na sua opinião, sufocava. Nessas condições, o veículo do sonho era, antes de mais nada e essencialmente, a escrita. (Roubine 1998: 49)

Por outro lado, Roubine afirma a importância do movimento simbolista no histórico do teatro ocidental, afirmando que era a "primeira vez desde o classicismo, que a representação se via desligada da obrigação mimética e da sujeição a um modelo inspirado 
no real" (Roubine 2003: 121). Em contraposição principalmente ao naturalismo de Antoine, o teatro simbolista preconizava as questões da imaginação e do sonho, propondo estruturas outras para a construção da dramaturgia.

Porém, são poucos os registros teóricos que dão conta da visão desses artistas acerca do Simbolismo no teatro. Essas visões por muitas vezes são contraditórias e fogem às características mais importantes do movimento como um todo. Com isso, para dar conta do pensamento em teatro a partir do movimento simbolista, faz-se importante e até imprescindível refletir sobre a obra poética e reflexiva de Stephane Mallarmé, como veremos mais adiante na segunda parte deste estudo.

Por ora, nos interessa saber que a questão fundante da obra de Mallarmé, tanto na sua poesia, prosa, ou em suas investidas dramatúrgicas, se dá na necessidade de criar uma palavra que sugira um significado e não nomeie objetos. O símbolo opera de forma a expandir a imaginação dos leitores e retira a necessidade de através das palavras, nomear o mundo.

Porém, quando Mallarmé tentou propor aos teatros franceses uma montagem de suas obras, por vezes foi negado com a alegação de que a falta de materialidade de seus textos e a ausência quase que total de qualquer relação com o real ou ainda qualquer preceito fundante do drama, não cairia no gosto do público.

Essa necessidade de pensar o teatro como uma materialidade gera uma crise na criação de Mallarmé por exigir do escritor um equilíbrio na construção do seu universo onírico e intuitivo. Essa dicotomia entre a materialidade do teatro e a subjetivação da poesia acaba percorrendo toda a sua obra, deixando sempre obscuro o limite entre a dramaturgia e a poesia.

É tímida ainda a bibliografia que se debruça a pensar a obra de Mallarmé como propositiva e vanguarda na construção de um pensamento sobre o teatro. Com obras já consagradas na área da poesia, o cerne de sua obra contém uma elaboração que é basilar no pensamento das artes cênicas: a noção de corpo na palavra. O ponto de partida de sua poesia é a performance, o acontecimento, o que denota uma relação intrínseca e inseparável de sua obra poética com os preceitos do palco. Frantisek Deak acreditava que havia uma teatralidade por trás de cada verso dos poemas de Mallarmé (apud Moler 2006: 
57). Essa afirmação reforça a ideia de que as palavras, os escritos de Mallarmé demandavam ou afloravam uma condição espetacular, que imbrica a necessidade de uma voz, de um corpo.

\subsection{Texto como Espetáculo}

A concepção de texto para a semiótica em geral ganha contornos mais abarcantes do que a ideia comum de texto enquanto produção escrita. Dessa forma, a ideia de um texto pode analisada em diversas outras linguagens que não possuem somente a escrita como meio de comunicação. Para a semiótica, a leitura de um texto pode ser realizada, por exemplo, numa pintura, numa propaganda, num filme ou até mesmo numa música.

Assim a ideia de um texto passa a ser considerado como "ogni unità concreta di discurso - sai essa di tipo verbale, non verbale o misto - que risulti dalla coesistenza di più codici" (De Marinis 1978: 68). É essa concepção que o teórico italiano Marco De Marinis toma de pronto para a construção de uma semiótica teatral.

Fazendo uso desse entendimento mais abrangente de texto, De Marinis constrói, ainda no final da década de 70, uma forma de análise do espetáculo a partir da concretude do "texto espetacular" o qual ele define como "unità di manifestazione teatrale che sono gli spettacoli, colti nel loro aspetto di "processi" significante complessi, verbali e non-verbali insieme" (Ibidem).

No artigo "Lo spettacolo come texto", De Marinis acaba por descrever aspectos de análise do teatro, com o intuito de descrever os elementos de um texto espetacular, o que acaba também por auxiliar no entendimento da construção do espetáculo sem o auxílio estrutural do texto dramático. No decorrer do estudo ele cita vários exemplos de grupos e espetáculos que são construídos e que podem ser analisados fora dos parâmetros do drama. Ele elenca várias categorias para clarificar a análise do espetáculo, como: sistema plural e sistema singular; estrutura parcial e macroestrutura; pluralidade da leitura e pluralidade de estrutura; e etc.

A análise de De Marinis é extremamente referenciada pelo trabalho singular na leitura do teatro como linguagem autônoma e independente da hegemonia do drama. A ideia de que a cena possui um texto independente acabou por ampliar os estudos do teatro, 
antes mais focado na investigação dos textos escritos para a cena, da literatura dramática somente.

Porém, a teoria do italiano não se mostra ilesa às críticas que a semiótica como um todo vem levantando desde a sua criação. A invenção de parâmetros para a leitura e análise de uma obra a partir da compreensão dos signos que a compõe por vezes é tomado como uma delimitação das investigações que, emolduradas nas classes indicadas pela semiótica, acaba por limitar a obra em prol da categorização da mesma. Por diversas vezes, a análise acaba por diminuir a abrangência de significados ao delimitar e enquadrar as proposições de acordo com os parâmetros da semiótica.

Porém, para além dessa crítica recorrente e amplamente discutida no que concerne principalmente os estudos literários, se faz extremamente importante para este estudo a discussão do seguinte trecho do texto de De Marinis:

In proposito occorrerà ribadire drasticamente che la distanza che separa la messa in scena virtuale inscritta in un testo drammatico (ammesso che cia possible e abbia senso "ricostruila) da una o piu messe in scena reali concrete di que testo (I'unico oggetto pertinente di una semiotica teatrale propriamente detta), non è colmabile finchè si resta sul piano del testo scritto (comunque letto e analizzato) e non ci si decide a prendere in esame la sua transcodificazione scenica in una concreta occorrenza spettacolare. Qui non si sta mettendo in dubbio - sia chiaro - la legittimità di una semiotica del testo drammatico, si sta solo criticando la pretesa - presente in alcuni studiosi - di scambiare il testo scritto per lo spettacolo, o meglio, di ritenere il secondo "incluso" nel primo, quando è semmai vero il contrario. (Idem: 67)

[Sobre isso será necessário reiterar drasticamente que a distância que separa a cena virtual inscrita num texto dramático (admito que é possível e faz sentido reconstruí-la) de uma ou mais encenações real/concreta do texto (o único objeto relevante de uma semiótica teatral propriamente dita), não é transponível desde que permaneça no plano do texto escrito (ainda lidos e analisados) e não é possível considerar a sua transcodificação cênica em uma concreta ocorrência espetacular. Aqui não se está questionando - é claro - a legitimidade de uma semiótica do texto dramático, se está somente criticando a afirmação - presente em alguns estudiosos - de trocar o texto escrito pelo espetáculo, ou melhor, de sentir o segundo incluso no primeiro, quando é mais verdadeiro o contrário.]

De Marinis deixa claro que a posição cenocentrista que defende é uma oposição direta à condição do texto dramático. Em nenhum momento o teórico utiliza a concepção de 
dramaturgia ou de texto escrito sem considerar a concepção dramática. Porém, por se tratar de um artigo escrito em 1978, quando as obras de ícones do teatro textual já foram amplamente divulgadas, como é o caso de Beckett, Arrabal, Ionesco, e outros, podemos contestar a abrangência da leitura de De Marinis ao afirmar que é a ausência de espetacularidade que justifica a crítica ao texto teatral.

Neste trecho acima o teórico italiano deixa clara a ideia de que não é possível haver no texto teatral construções que indiquem uma espetacularidade em si mesmo. Ele afirma que a análise semiótica que se dá no texto escrito não pode abarcar questões que são analisadas no espetáculo, porém a análise texto pode e deve fazer parte da análise espetacular.

A oposição a este argumento é exatamente o que se pretende esclarecer neste presente estudo. Almeja-se, portanto, indicar que há nos textos teatrais contemporâneos, alguns aspectos que conjugam com a construção de um texto espetacular, ou de um texto como espetáculo.

É importante ressaltar aqui que a concepção de texto como espetáculo ao qual De Marinis se opõe é completamente aderente à concepção de texto dramático, oposição que também somos adeptos. Porém, a resposta a essa oposição para o pesquisador italiano é justamente a exaltação do cenocentrismo que, em valorização das questões do espetáculo, não abarca textos que tem no cerne justamente uma nova/outra maneira na relação texto/cena.

\subsection{Oximoro Texto versus Cena}

Ao realizar leitura da obra de Platão, o pesquisador Luiz Fernando Ramos, a partir da análise de Stephen Halliwell, indica que a ideia de um mimesis configurada como uma representação do mundo pode ser contestada, já quem em outros textos de Platão, podemos encontrar a ideia de mimesis como "criação de um mundo distinto do existente, o que ele chamará de 'visão heterocósmica'”' (Ramos 2015: 251).

Em seu livro Mimesis Performativa - A margem de invenção possível Ramos afirma que a ideia de mimesis dramática está vinculada desde Platão ao acontecimento teatral, através da oposição mimesis versus diegesis. Para o filósofo, a diegesis estaria vinculada à 
outras narrativas que não se ocupam da relação interpretativa de atores. Portanto, a construção da mimesis, para Platão, está intrinsecamente aliada à possibilidade de uma cena.

Por outro lado, Aristóteles, ao articular seus pensamentos sobre o teatro e sobre os gêneros, não traz uma definição clara acerca de mimesis, mas coloca em sua Poética a elucidação sobre a oposição entre mythos e opsis para configurar um ideal de teatro. Nessa condição o mythos teria importância primordial, enquanto que a opsis, o espetáculo, estaria em sexto e último lugar na valorização dos elementos que constituem a tragédia.

O que o livro de Ramos demonstra em seu primeiro capítulo é a maneira como essa valorização de mythos e opsis vai se transformando, invertendo a ordem de importância, passando pela releitura aristotélica de Diderot, no teatro do silêncio e do gesto de Mallarmé e finaliza com completa a exaltação da cena na construção cenográfica de Gordon Craig.

Apesar de não ser o foco da discussão da obra de Ramos, o que achamos importante ressaltar é justamente a concepção de que o mythos e a opsis não estão intrinsecamente relacionados com a oposição entre texto e cena. O caminho percorrido pelo autor demonstra que a inversão da importância de mythos e opsis no teatro se deu por meio da recusa do texto dramático, mas não é oportuno dizer que o texto e a cena cumprem funções enrijecidas no teatro, o primeiro de narrativa e o segundo de espetacularidade.

Segundo Ramos, a falsa oposição entre texto e cena acaba por, até hoje, barrar a abrangência das experimentações do teatro que se dedicam a investigar a palavra, num preconceituoso engano. O pesquisador, ao citar a obra de Mallarmé como um oximoro na relação entre a palavra e a teatro, elucida-nos quanto a potência do texto para a cena e, para além disso, se mostra como forte propositor que, indo ao cerne do embate com o dramático - a retirada do logocentrismo - revela um forte e abrangente caminho para a superação da crise do drama:

O espetáculo, por sua vez, também se liberta do jugo do drama, passando a ser tecido, em hipótese, só com os corpos e a música, dissociados de sentidos prévios e de qualquer vínculo anterior. É nessa medida que o espetáculo imaginado por Mallarmé configura-se, literalmente, como um oximoro, ou seja, uma unidade dual, ou a identidade de diferentes, em que a literatura e o espetáculo, expurgando a ficção dramática, se radicalizam alternativamente no puramente literário e no puramente espetacular. Nos termos da "Poética" aristotélica, além do literário e do cênico serem depurados do 
dramático, dramaturgia - ficção, mythos - e cena - espetáculo, opsis - dissociam-se completamente. (Idem: 59)

É justamente a designação da relação entre texto e cena como um oximoro que nos interessa colocar neste momento. Essa falsa oposição que acaba por revelar uma conjunção é a proposição que intentamos discutir inicialmente neste estudo. É completamente possível perceber algumas instâncias do mythos e da opsis em ambos os elementos, o texto e a cena. Ramos diz que é impossível retirarmos completamente o mythos ou a opsis das proposições artísticas das artes cênicas, "de fato, tanto na leitura de Aristóteles como nas que se oferecem na contemporaneidade, mythos e opsis nunca estarão completamente dissociados e, mesmo que hegemônicos um frente ao outro, guardarão sempre um vínculo insuprimível" (Idem: 27). O que pretendemos então neste artigo - já que os estudos teatrais, em sua grande maioria, se ocupam de analisar e dar conta da opsis presente na materialidade cênica - é justamente perceber de que maneira o texto conjuga com elementos espetaculares e percebe em si próprio a exaltação e desenvolvimentos de aspectos da opsis.

\subsection{Dramaturgia Performativa}

No artigo O Sujeito da Língua Sujeito à Língua: Reflexões sobre a Dramaturgia Performativa Contemporânea o pesquisador Stephan Baumgartel inicia sua reflexão diferenciando o uso do signo e do significado na dramaturgia performativa. Para ele, o performativo é o movimento de materializar o signo, afastando-o do seu significado cotidiano. Neste sentido, o autor afirma que "os signos se apresentam, se instalam na cena, principalmente como realidade sensorial" (Baumgartel 2010: 111) distanciando-se da sua dimensão referencial, e tornando nebulosa a sua função mimética.

Essa modificação no uso dos signos retira o espectador da sua zona de conforto e reivindica: "Lide comigo!" (Idem: 112). A remoção do significado desbanca a narrativa fabular e propõe um olhar sobre a estrutura cênica que se constrói, o que além de dar uma abertura maior às leituras da obra também faz florescer uma posição crítica do espectador, não só racionalmente, mas principalmente intuitiva e subjetivamente.

As construções performativas do teatro contemporâneo se apresentam como que focadas mais na "construção de arranjos cênicos em vez de narrativas" (Ibidem), aspecto 
esse também presente como foco na elaboração da dramaturgia performativa. O lugar fabular da escrita é substituído por um engenho linguístico, pelo uso diferenciado da língua, criando um outro universo a partir das palavras, substituindo o entendimento racional por outras formas de percepção:

Nesta escrita performativa, o foco na língua enquanto habitat e ferramenta do discurso, enquanto fenômeno processual e meio de interpelação, faz com que a estrutura do texto teatral tome a língua como seu próprio material. Esta linguagem textual não descreve mais predominantemente personagens, mas o funcionamento produtivo da língua, ou seja, a relação dinâmica entre língua e consciência humana, entre discurso e percepção. (Idem: 114)

O que Baumgartel explicita é que com arranjo cênico e engenho linguístico se constrói uma maneira distinta de relacionamento entre texto e cena, em detrimento da soberania da fábula. Para ele, assim como o arranjo cênico, a língua também tem a mesma capacidade de subtrair a prioridade do enredo no teatro. Esse procedimento ressignifica a ideia de texto teatral como fábula e instaura a concepção de acontecimento na própria dramaturgia, reforçando seu aspecto performativo.

Uma das principais características da escrita performativa é a construção de uma língua independente de um mote realista, criando com ela outras maneiras de ocupar o espaço e o tempo, acessando outros modos de percepção e de vivência do teatro, fora do logocentrismo.

Para Baumgartel, este aspecto está relacionado à forma como encaramos e entendemos o falar no teatro. Tradicionalmente, na concepção dramática, falar é agir dentro do contexto ficcional, ou seja, a fala produz uma ação que faz a narrativa caminhar e o diálogo se efetivar como utilizamos cotidianamente - acessa-se uma fala representacional. Já no sentido performático, conforme Baumgartel, "um agir que é falar implica fazer através dos meios linguísticos com que a língua se revele nas suas dimensões criativas e interpelantes sobre seus usuários" (Idem: 124). Portanto falar é agir no sentido de que esta fala produz uma língua dinâmica, que nos desloca do universo conhecido e cotidiano da realidade.

Após o entendimento do que seria uma dramaturgia performativa - uma construção que parte da pesquisa e da inventividade da própria língua, recorreremos a outro estudo do 
pesquisador Baumgartel. Afim de esclarecer um tanto mais a falsa oposição entre texto e cena, utilizaremos o artigo "Em busca de uma teatralidade textual performativa além da representação dramática: reflexões sobre a verdade formal na dramaturgia contemporânea". Nesta análise, ele classifica os textos teatrais em três possibilidades: os textos dramáticos; os textos não-dramáticos e os textos performativos. Nos interessa neste momento discutir a diferença entre os textos não-dramáticos e os textos performativos.

Para Baumgartel, os textos não-dramáticos são aqueles cujas unidades de ação, tempo e espaço não são compostas de acordo com a lógica dramática, porém toda a construção fabular e representacional ainda é mantida, mesmo que articulando tempo e espaço de maneira fragmentária:

Este modelo contemporâneo possui sua funcionalidade principalmente na 'desconstrução dos princípios de narração e figuração, e na transferência contínua e coerente dos processos de significação do texto para o público. Nisso, a representação cênica de uma ficção deixa de ser o elemento central, em prol da autorreflexão do teatro'. Os vários tipos de escrita não-dramática que ela esboça são manifestações desta função analítica do texto teatral, organizadas segundo a sua crescente distância de uma estética referencial realista e a sua crescente proximidade com uma estética performativa. (Baumgartel 2009: 143)

Já a sua concepção acerca do texto performativo trata justamente de uma mudança na base do pensamento do texto teatral: se trata da criação não representacional de um texto, revelando, portanto, outros formatos linguísticos que não aderem mais à lógica da construção fabular e comunicação indicativa. Neste caso, o que se refuta é justamente construção de sentidos fechados, no qual o processo de significação não é mais operação primordial. Portanto,

O que interessa para este processo de significação é a criação de um mundo estético que se autossustenta, ou seja, um universo semiótico com meios linguísticos que não se justifica por seu valor referencial, mas pela eficácia autopoética e performativa. Seu centro de significação reside em seu funcionamento semiótico, em sua estrutura e no modo como este texto subverte em sua forma a dominância do lado referencial do signo linguístico. (Idem: 128) 
Desse modo, a reflexão acerca das novas produções textuais para o teatro a partir do século XX trata justamente de um redirecionamento da função representacional do teatro para uma produção performativa passível de construção a partir de outros parâmetros nãoindicativos, sempre ancorados no encontro com o seu público, parte constituinte da obra.

\subsection{Síntese: A Problemática do Textocentrismo}

A partir da apresentação dos tópicos acima, podemos indicar algumas condições:

1. A possibilidade de perceber a influência do gênero lírico no teatro como forma de oposição à hegemonia do dramático traz a percepção de que a palavra pode se engendrar para caminhos não-narrativos. A abrangência da leitura de Peter Szondi, tendo Brecht como ícone da reformulação do drama, acaba por inaugurar a construção de um pensamento cenocentrista. Dessa forma, a falta de espaço para a discussão acerca do lírico no teatro acaba também por instaurar uma falha na discussão acerca do texto teatral, já que os escritos ditos representantes do drama lírico, também são tomados como textocentristas.

2. A Poética Simbolista diante à crise do drama é um dos primeiros movimentos que pretende reformar o teatro a partir da própria palavra. Atestada como uma volta ao textocentrismo, ao ter o texto e a palavra como possíveis saídas para a crise, nos faz percebê-la historicamente como uma das primeiras tentativas de se instaurar o texto enquanto recusa ao logocentrismo e uma aproximação da palavra como presença, diante da reformulação do dramático.

3. A leitura semiótica de Marco De Marinis acaba por revelar a necessidade de sufocamento do texto em detrimento da cena. Para além das críticas intrínsecas à teoria semiótica, a apropriação dessa proposição para o teatro acaba por enfatizar a ideia errônea de que o texto escrito não contém aspectos do espetáculo. Para o teórico italiano é possível a leitura de um texto (enquanto uma unidade de discurso, verbal ou não) no espetáculo, porém, o oposto não é possível. A aversão a essa leitura também é base para o que pretendemos construir neste artigo. Defendemos a leitura de algumas dramaturgias da contemporaneidade como exemplos de desenvolvimento de aspectos do espetáculo no texto, ressignificando a oposição texto e cena e propondo uma outra visão acerca da palavra no teatro fora dos parâmetros fabulares. 
4. A oposição cunhada por Aristóteles entre mythos e opsis, acaba por construir uma falsa correspondência à concepção texto e cena. Considerando que os elementos da tragédia não se dissociam completamente, podemos alegar que a afirmação hegemônica de que o texto suplanta toda elaboração da cena, acaba por construir um oximoro. Nesta conjunção nos interessa reforçar a possibilidade espetacular do texto ao colocar a opsis em evidencia e se afastando do mythos, comprovando a possibilidade textual de construção espetacular.

5. A proposição de uma dramaturgia performativa para o pesquisador Stephan Baumgartel passa por dois aspectos basilares: o tensionamento da relação significado e significante e a construção de engenhos linguísticos. Nestas duas operações a base de inventividade do texto está na pesquisa da própria língua. Neste contexto, a língua toma uma posição central na construção da dramaturgia por conter em si mesma a capacidade de transformar a palavra em ação. Essa capacidade traz para a dramaturgia a possibilidade de ser construir a ação teatral a partir da palavra, através da própria língua, retirando de seu centro qualquer aspecto representativo/logocêntrico e instaurando a presença e a performatividade no próprio texto.

6. A diferenciação de textos não-dramáticos e textos performativos realizada pelo pesquisador Stephan Baumgartel é fundamental para o entendimento das características do texto na contemporaneidade. $O$ entendimento de que o simples tensionamento de unidades de tempo, espaço e ação não contribuem para a construção de uma linguagem performativa, já que elas podem, da mesma forma, exaltar a narrativa e a construção logocêntrica da mesma forma, é fundamental. É com essa afirmação que nos apoiamos ao afirmar que mesmo um teatro cenocentrista ainda contribui para a criação de uma cena logocentrista, um dos pilares do drama. Portanto, a ausência de um texto não garante que uma obra teatral não esteja alicerçada em parâmetros do drama, mesmo que a materialidade do teatro esteja exposta. A partir dessa leitura a ideia de textocentrismo enquanto característica dramática, acaba por ser questionada.

Portanto, podemos afirmar que encontramos ainda hoje discursos cenocentristas que reforçam a condição representacional como própria do texto e da palavra. E mais ainda, alguns discursos indicam que, caso algum texto não seja construído de acordo com os 
direcionamentos dramáticos, se trata de um esforço por parte dos dramaturgos em dialogar com a cena autônoma e independente do texto, e não de uma inventividade possível na própria palavra.

A recusa ao representacional e às proposições logocêntricas e hierárquicas ainda se confundem com uma rejeição ao texto teatral. Sabemos que historicamente essas duas questões estão imbricadas uma na outra, porém, como tentamos demonstrar ao falar do simbolismo, por exemplo, é que uma parte das produções textuais contemporâneas trabalham e se esforçam em se afastar da representação e o logocentrismo, abrindo outras formas de relação com a palavra.

Há a sensação, portanto, de que, para acompanhar e dar cabo das novas necessidades do teatro, na descoberta da materialidade cênica como seu elemento principal, o texto deve se render às condições da cena e, numa oposição forte ao seu status anterior, dar espaço à produção cênica através de indecisões textuais e ausência de indicações para deixar surgir a criação do encenador e sua equipe - verdadeiros fazedores da arte teatral.

Percebe-se ainda que, em algumas pesquisas, há um olhar sobre o texto teatral contemporâneo de forma a colocá-lo como que regenerado pela condição cênica do teatro. Vê-se o texto teatral como um material que, derrotado pelo teatro cenocentrista, encontrase rendido às condições da materialidade da cena.

Porém, ao atentar que antes de uma recusa ao texto, trata-se da necessidade de uma recusa ao logocentrismo, ao representacional, percebemos que a crise do teatro se trata também de uma crise representacional da própria linguagem e não do texto. A partir do instante em que a linguagem se vê liberta de sua função representacional, o uso da palavra não-comunicacional se torna tão performativa e antiteatral como o desenvolvimento de uma cena não representacional com ausência de texto.

Nesse interim, percebemos que não se trata de inserir no texto teatral uma abertura para a cena. Não se trata, também, de perceber as possibilidades de interação entre texto e cena, investindo na possibilidade de jogo, de conexão, de movimentos de abertura e proposição textual. Trata-se antes da possibilidade de se construir um texto em que se 
encontram aspectos da presença e da recusa ao logocentrismo, evidenciando a configuração espetacular em si próprio e exigindo ainda mais da construção cênica.

O que pretendemos, de certa maneira, é também questionar o uso que se faz do termo textocentrismo como sinônimo de logocentrismo. Obviamente que o textocentrismo se fez extremamente necessário ao formato do drama, reforçando ainda mais uma condição hierárquica. Mas o que pretendemos combater é a ideia de que a própria condição textocentrista de um espetáculo teatral já é o suficiente para que ele seja lido como produtor de $\operatorname{logos}$ e, consequentemente, adepto ao formato do drama. Neste caso, acreditamos que o problema da cena textocentrista é justamente o mesmo de uma cena cenocentrista: a existência de uma hierarquia nos elementos teatrais. Portanto, a oposição que buscamos enfatizar não está centrada na configuração texto versus cena e sim, no logos versus performativo.

\section{Bibliografia}

Balakian, Anna (1985), O Simbolismo, São Paulo, Perspectiva.

Baumgartel, Stephan (2010), “O Sujeito da Língua Sujeito à Língua: Reflexões sobre a Dramaturgia Performativa Contemporânea", Revista VIS, v. 9, Brasília, UNB.

-- (2009), “Em busca de uma teatralidade performativa além da representação dramática: reflexões sobre a variedade formal na dramaturgia contemporânea", in: Sobre PerformAtividade, Florianópolis, Letras Contemporâneas.

De Marinis, Marco (1979), "Lo spettacolo come texto", Versus - Quaderni di studi semiotici, n. 21, Bompiani. 
Mendes, Cleise Furtado (2015), "A ação do lírico na Dramaturgia Contemporânea", Revista Aspas, v. 5, n. 2, São Paulo. <http://www.revistas.usp.br/aspas/article/view/102334>

Moler, Lara Biasoli (2006), Da Palavra ao Silêncio: o teatro simbolista de Maurice Maeterlink. São Paulo. < <http://www.teses.usp.br/teses/disponiveis/8/8146/tde-08082007-155902/ptbr.php>

Ramos, Luiz Fernando (2015), Mimesis Performativa: A Margem de Invenção Possível, São Paulo, Annablume.

Roubine, Jean-Jacques (1998), A linguagem da encenação teatral, Jorge Zahar Editor, Rio de Janeiro.

-- (2003), Introdução às grandes teorias do teatro, Jorge Zahar Editor, Rio de Janeiro.

Sarrazac, Jean-Pierre et al. (2012), Léxico do Drama Moderno e Contemporâneo, Cosac Naify, São Paulo.

Szondi, Peter (2001), Teoria do Drama Moderno [1880 - 1950], Cosac Naify, São Paulo.

Lígia Souza de Oliveira é pesquisadora, dramaturga e professora. Doutoranda em teatro pela Universidade de São Paulo - Brasil com período sanduíche na Universidade Paris 8 Saint Denis - França e bolsista da Fundação de Amparo e Apoio à Pesquisa de São Paulo. Fez o mestrado em Literatura, na Universidade Federal do Paraná, e graduou-se em Artes Cênicas, pela Faculdade de Artes do Paraná. Publicou as dramaturgias, encontros e diários, pela coleção Dramaturgias Curitibanas e personne, que compõe a Coleção Drama e é também editora da Revista Aspas, na Escola de Comunicação e Artes. 